\title{
Beyond the Transboundary River: Issues of Riparian Responsibilities
}

\author{
P. K. Parhi $\cdot$ R. N. Sankhua
}

Received: 15 February 2013/ Accepted: 13 April 2014/Published online: 15 May 2014

(C) The Institution of Engineers (India) 2014

\begin{abstract}
The issues of riparian countries sharing transboundary waters spans decades, and has been greatly strengthened by its collaboration with partner agencies. International cooperation on shared water resources is critical, especially in water scarce regions experiencing the impacts of over-consumption and pollution. Where, river basins are transboundary, this requires regular and structured consultation, coordination and cooperation among all states sharing the catchment. Rapid and unsustainable development of river basins and their wetlands has led to the disruption of natural hydrological cycles. In many cases this has resulted in greater frequency and severity of flooding, drought and pollution. Appropriate transnational planning, protection and allocation of water to wetlands are essential to avoid disaster and enable these ecosystems to continue to provide important goods and services to local communities. Integrated river basin management takes into account policies and measures for the multifunctional use of rivers on a catchment scale and associated institutional changes. The implementation of these involves a number of steps such as definition of aim, construction of conceptual model, selection of variables, comparison with selection criteria, database assessment, and indicator selection division of tasks and responsibilities for river basin management with regard to the development of indicators, data collection, and their application in decision-making. This work presents issues pertaining to the pressure to the river,
\end{abstract}

P. K. Parhi $(\square)$

Center for Water Engineering and Management, Central

University of Jharkhand, Ranchi 835205, India

e-mail: prabeer11@yahoo.co.in

R. N. Sankhua

National Water Academy, Pune, India the state of the river ecosystem, the impact to goods and services provided by the river, and the societal response.

Keywords Riparian water rights .

Trans-boundary waters $\cdot$ River basins .

Integrated management $\cdot$ International laws

\section{Introduction}

The sustainable management of the 263 transboundary rivers or lakes and many hundreds of aquifers, the basins of which contain more than half the territory and population of the world, presents major challenges and is of strategic importance in the immediate and long-term future [1]. There are 59 transboundary river basins in Africa alone, accounting for $80 \%$ of the continent's surface water resources. Management of these essential shared resources is crucial for poverty reduction strategies. Sustainable transboundary water resources management requires:

1. Sharing water-related benefits among nations for regional economic integration rather than polarized claims for water;

2. Recognizing the fundamental need of freshwater ecosystems for resource protection and natural risk prevention;

3. Balancing competing uses of basin and aquifer resources, especially upstream and downstream uses, in a transparent and participative way for local and regional sustainable development;

4. Focusing on poverty reduction, public participation and gender balance to ensure equitable access to water for livelihoods;

5. Developing capacity building on integrated water resources management (IWRM). 
6. Protecting watercourses during wars and conflicts and post-conflict rehabilitation of water resources;

7. Improving present knowledge of conflicts and potential policy responses to prevent conflicts triggered by competition for the resource among different uses and users, and environmental concerns such as pollution; and the relevant areas.

\section{Water Right Theories}

Pertinent to the context, with regard to the water rights of different riparian state, the theories for the concern [2] are: (1) territorial sovereignty theory; (2) natural water flow theory; (3) equitable apportionment theory; and (4) community of interest theory.

The territorial sovereignty theory is also known as the Harmon doctrine because it was put forward by the US Attorney General Harmon in 1896 in connection with the controversy between the United States and Mexico over the use of the waters of the river Rio Grande. This theory holds that riparian states have exclusive or sovereign rights over the waters flowing through their territory.

The natural water flow theory is also known as the territorial integrity theory. Since a river is a part of the territory of the state under this theory every lower riparian owner is entitled to the natural flow of the river unhampered by the upper riparian owners, otherwise it results in violation of its territorial sovereignty. In other words, the upper riparian owner must allow the water to flow in its natural course to the lower riparian owner in its ordinary channel though, of course, the former can make reasonable use of the water while it was in his territory. This principle has been drawn from the British cases dealing with private property rights in water in a unitary state. Legal thinking on water rights and water conflicts has so far rejected the natural flow theory. However, the emergence of ecological thinking shows that water projects have high ecological and social costs, and some form of the natural integrity doctrine will need to re-emerge to resolve water conflicts in an ecological era.

The equitable utilisation and community of interest theories are closely interrelated. In international law the equitable utilisation of an international river by different states is gaining acceptance. Recent Helsinki Rules have adopted this theory as the basis of international law with regard to the sharing of waters of an international river by different riparian states. The idea of equitable utilisation is the sharing of waters of an international river by various states on an equitable basis.

The equitable apportionment formula used to resolve inter-state conflicts do not lend itself to precise articulation or rules. It is difficult to evolve principles for determining the equitable share of each riparian state which may apply in all cases or situations. The underlying postulate of equitable apportionment is equitability and not equality. The idea is the maximum benefit accruing to all the riparian states of the river, keeping in view the economic and social needs of the different riparian states. The problems of each state and river are unique and a solution in one case may not be feasible for adoption in another. The working out of an equitable share of each basin state requires an analysis of complex technical and economic data and the judicious balancing of conflicting claims of, and uses of the river by different riparian states. The problem is further complicated by the fact that the diverse uses of the river by the different states are not simultaneous. Depending upon the needs and the economic development of a state these uses are at different points of time.

The first component of the equitable formula is that the use which is to be protected must be beneficial to the state. Thus the Helsinki Rules [3] state, 'Each basin state is entitled, within its territory, to a reasonable and equitable share in the beneficial uses of the waters of an international drainage basin'. Explaining the terms, 'beneficial uses', the comment on the article says that 'it must be economically or socially valuable, as opposed, for example, to a diversion of waters by one state merely for the purposes of harassing another'. Further, the "beneficial use" need not be the most productive use to which the water may be put, nor need it utilize the most efficient methods known in order to avoid waste and insure maximum utilisation.

Equity has been defined within this narrow framework, in which what is essentially protected is the right to 'develop' a river and dam and divert its waters. During the period of the technological euphoria of large dams, dams and river diversions were assumed to lead to undiluted benefits. Concepts of water rights as used currently are concepts of the rights of a state to control or consume water through large water projects. Rules on water use have been framed to protect the rights of states to build dams. This is clearly stated in the Krishna Tribunal, which recommended the establishment of the Krishna Valley Authority. The Tribunal states: 'It shall be the duty of the Krishna Valley Authority to ensure that the waters of the river Krishna are stored, appropriated and used to the extent and in the manner provided'.

Article VIII (I) of the Helsinki Rules provides that 'An existing reasonable use may continue in operation unless the factors justifying its continuance are outweighed by other factors leading to the conclusion that it be modified or terminated so as to accommodate a competing incompatible use' [3].

As noted by critics, the rule embodied in this Article gives some weight to the existing use but not conclusive. 
Indeed, it is conceivable that, if a state moves quickly enough, it could appropriate all of the waters of a basin to the complete exclusion of its co-basin states. But, if no weight is given to the existing uses, it would inhibit river development, as no state would like to invest huge sums of money in the construction of dams and other works if it has no reasonable assurance of the continuance of its use of the waters.

\section{International Law and Water Rights}

Neither international law nor national law related to water rights has evolved to respond to the ecological and political challenges posed by water conflicts that are emerging because people's survival needs and nature's sustenance needs have been ignored [4]. No legal document mentions the most basic law related to water-the natural law of the water cycle. Protection is limited to man-made concrete structures, and from this limited concept of water rights emerges the competitive scramble for each region and state attempting to outdo the other in planning water projects as a means of establishing their rights to water. Water conflicts thus grow exponentially with large water projects, in spite of the establishment of legal frameworks to resolve these conflicts.

Sustainable water resources management is essential for achieving the development goals, ecosystem protection and social and political stability across the world. Water is a possible cause of tension but also, more importantly, a powerful source of cooperation. However, many longstanding water-related disputes still remain unresolved, and the growing demand for finite freshwater resources heightens the risk of future conflicts.

\section{Sharing Benefits}

Discussions on transboundary cooperation should be based on recognition of interdependence and highlight the myriad benefits of integrated management at the river, lake, basin, and aquifer levels for all States involved. Redistribution of these shared benefits at the national level needs stakeholder participation and integration of poverty reduction strategies.

\section{Environment}

The importance of the integrity of ecosystems must be incorporated within interstate and basin agreements. Healthy and functioning ecosystems are vital to safe and clean water supplies and risk prevention. Moreover, the biodiversity of rivers and lakes is a vital element of food security in many parts of the world. Goals for equitable water access and cooperation will remain insignificant if investment in the health of rivers as the source of water for people and nature is ignored. Steps need to be taken to implement environmental flows, where sufficient and nonpolluted water is allocated to maintain healthy river systems, estuaries and coastal areas for the benefit of people and the environment.

\section{Indian Perspective}

In India the position has been well recognized that no state can be given an entirely free hand in respect of a common source of water such as an inter-state river. Inter-state rivers are for the general welfare of all the states through which they flow irrespective of political boundaries. The Harmon doctrine has never held sway in India. Under the Government of India Act, 1935, even though water supplies, irrigation canals, drainage and embankments, etc. were included in the Provincial Legislate List, Sections $130-132$ of the Act imposed certain limitations on the provinces in the use of inter-state river waters.

Under the Constitution of India also, a co-riparian state is not free to develop an inter-state river regardless of the harm to other co riparian states. This is evident from the fact that the Constitution in Article 262 has empowered Parliament to provide 'for the adjudication of any dispute or complaint with respect to the use, distribution or control of the waters of, or in, any inter-state river or river valley [5].' There would have been no necessity for such a provision if the Harmon doctrine were the governing law. Though Parliament has provided the adjudicatory machinery in the Inter-State Water Disputes Act, the statute is silent as to the principles to be followed in the settlement of inter-state water disputes. The principle adopted in the resolution of inter-state water disputes in the preindependent and post-independent period in India, has been the equitable allocation of waters among the states to ensure 'each unit getting a fair share of the water of the common river'.

There is an internationally accepted principle [6] aimed at a just resolution of river conflicts between countries and between states does not, by itself, ensure justice. First, each basin is so distinct that the most sustainable and just use of water will be diverse, not monolithic. Second, given this ecological diversity, the basic principle of equitable utilisation emerges as vague. This principle is no more than a set of recommendations from a nongovernmental scientific organisation. First, the principle treats water like other resources, static and fixed, to be cut up and divided. But in river waters, what is distributed is a flow-and because water 
is a flow, not a stock, its distribution has non-heal impacts. The distribution of benefits and losses to regions involved in an upstream-downstream relation, or in non-riparian states deriving water use benefits, are changing over time, as are the implications of the equitable sharing concept. Technological changes which contribute to river water diversions also change the mutual situation and have implications for an equitable sharing concept.

The issue is not one of maintaining a balance between territorial sovereignty and riparian rights. Ecological conflicts over river waters are indicative of the limits within which water re-distribution can take place. While natural flow is not an absolute criterion, conserving rights distributed ecologically is a criterion. Water projects have severe ecological impacts and costs are unequally distributed between states and between social groups. The ecological perspective also helps correct the view that water conserved is water 'wasted'. Ecologically, unexploited water can be critical in maintaining essential ecological processes such as recharge of groundwater, and maintaining the sea water-flesh water balance in the delta.

\section{International Cooperation}

Countries sharing a drainage basin are encouraged to establish frequent specific contacts in order to exchange information on the water resource and its management. Options for this include:

1. Sharing of information on structural and non-structural mechanisms for regulating flow for navigation and flood prevention;

2. Establishing networks for monitoring and exchanging data on the water quality and quantity;

3. A joint analysis of information on the quantity and type of water used for various purposes in each country; and

4. Exchange of information on protection measures for groundwater, upper catchments and wetlands;

The aim should be the preparation of technical reports on the river basin, including information on the needs of the local inhabitants in each part of the basin, as well as existing or potential problems in parts of the river basin that require separate or collaborative efforts to deal with them.

In October 2000, the European Union adopted an operational tool for a modern water policy: the "Water Framework Directive" (WFD) which aims to expand the scope of water protection to all waters, surface waters and groundwater, to achieve "good status" for all waters by a set deadline, to undertake water management based on river basin management, using a combined approach of emission limit values and quality standards in order to getting the prices right, the citizens involved more closely, and to streamline legislation.

These objectives must be integrated for each river basin, for which detailed objectives have to be established. Subsequently, an analysis of human impact is conducted so as to determine how far from the objectives each body of water is. If the full objective of the WFD is not attained, the Member State must identify additional measures to satisfy all established objectives. These might include stricter controls on polluting emissions from industry and agriculture, or urban waste sources. The river basin management plan should specify the river basin's characteristics, and provide a review of the impact of human activity on the status of waters in the basin, as well as an estimation of the effect of existing legislation to meet the "good quality" objectives, and a set of additional measures, where needed. An economic analysis of water use within the river basin should be carried out. This is to enable a rational discussion on the cost-effectiveness of the various possible measures. Member States are required to ensure that the price charged to water consumers reflects true costs, although in lessfavoured areas, deviations from this may be possible so that basic services are provided at an affordable price.

\section{The Issues of Ownership of River Water}

Lot of research efforts went into understanding of gains and losses from tenancy reforms and conferment of land rights. However, in the case of water resources, the ownership and use rights vary across water sources, usage and countries. The water use is guided by multiple property regimes viz. common property, common pool resource, private resource and state owned regime. The issue is further complicated when ownership and use are combination of these regimes. There is the perception of water users about the resource, which ultimately guide its usage pattern and efficiency of use or sustainability of the resource. Issues relating to ownership of water are not only complex but also different than for other resources. The use, control and ownership of water are linked to the ownership of land and irrigation structures. Thus, water ownership issue cannot be discussed in isolation. Further, ownership issue relating to surface water and groundwater needs to be dealt with differently. Watershed or inter-basin management programmes have suffered setback mainly on account of not being able to address the issue of ownership domain. Establishment of some sort of water rights and responsibility system, specifying the withdrawal or entitlement of water, is critical for prudent use of the resources. 


\section{Conclusion}

Water resource planning, administration and management should take into account the principles of access, justice and social equity as water is a precious natural and common property resource, vital to the sustenance of bio species life, policies, legal framework. Three goals of ecological security could be addressed by the water rights, i.e. economic efficiency and social equity. While the ecology and equity could be taken care at the stage of allocation of water rights, efficiency could be achieved at the stage of water utilization through the transferability of water rights. The doctrine of riparian rights needs to be properly interpreted. If incorporation of notions of accountability and provision for expeditious remedies for violation of rights is appropriately done, it would lead to better management of the resources. The international community at technical level needs to hammer out the tools in a concerted manner for the benefit sharing in transboundary settings to promote co-operation in other spheres. Time has come to think beyond natural water flow theory/ territorial integrity theory, equitable apportionment and water rights of riparian countries sharing transboundary waters, at least considering the shrinking of land resources in countries located over deltaic plans as a result of rising of ocean water level countries due to global warming be debated at all levels recently, other environmental changes resulting from human intervention and/or gifted by nature itself.

\section{References}

1. News Letter No. 39, (2003) Department for Economic and Social Affairs, United Nations, New York and the Economic Commission for Latin America and the Caribbean, Santiago, Chile

2. A.T. Wolf, Conflict and Cooperation along International Waterways, Water Policy -1, pp. 251-256 (1998)

3. Helsinki Rules on the uses of Waters of International Rivers, 52nd Conference, Helsinki (1966)

4. M.A. Giordano, A.T. Wolf, Sharing of Waters, Post Rio International Water Management, vol. 27, Issue 2, (2003)

5. Gazette of India, (Extraordinary) Part-II, Sec-3, Sub-section 2 (2002)

6. A.K. Biswas, Management of international waters: problems and perspective. Water Resour. Dev. 9(2), 167-188 (1993) 